\title{
The Scaffold Protein NHERF2 Determines the Coupling of P2Y1 Nucleotide and mGluR5 Glutamate Receptor to Different Ion Channels in Neurons
}

\author{
Alexander K. Filippov, ${ }^{1}$ Joseph Simon, ${ }^{2}$ Eric A. Barnard, ${ }^{2}$ and David A. Brown ${ }^{1}$ \\ ${ }^{1}$ Department of Neuroscience, Physiology and Pharmacology, University College London, London WC1E 6BT, United Kingdom and ${ }^{2}$ Department of \\ Pharmacology, University of Cambridge, Cambridge CB2 1PD, United Kingdom
}

\begin{abstract}
Expressed metabotropic group 1 glutamate mGluR5 receptors and nucleotide P2Y1 receptors (P2Y1Rs) show promiscuous ion channel coupling in sympathetic neurons: their stimulation inhibits M-type $[\mathrm{Kv} 7, \mathrm{~K}(\mathrm{M})]$ potassium currents and N-type $\left(\mathrm{Ca}_{\mathrm{V}} 2.2\right)$ calcium currents (Kammermeier and Ikeda, 1999; Brown et al., 2000). These effects are mediated by $G_{q}$ and $G_{i / 0} G$-proteins, respectively. Via their C-terminal tetrapeptide, these receptors also bind to the PDZ domain of the scaffold protein NHERF2, which enhances their coupling to $\mathrm{G}_{\mathrm{q}}$-mediated $\mathrm{Ca}^{2+}$ signaling (Fam et al., 2005; Paquet et al., 2006b). We investigated whether NHERF2 could modulate coupling to neuronal ion channels. We find that coexpression of NHERF2 in sympathetic neurons (by intranuclear cDNA injections) does not affect the extent of M-type potassium current inhibition produced by either receptor but strongly reduced $\mathrm{Ca}_{\mathrm{V}} 2.2$ inhibition by both P2Y1R and mGluR5 activation. NHERF2 expression had no significant effect on $\mathrm{Ca}_{\mathrm{v}} 2.2$ inhibition by norepinephrine (via $\alpha_{2}$-adrenoceptors, which do not bind NHERF2), nor on $\mathrm{Ca}_{\mathrm{v}} 2.2$ inhibition produced by an expressed P2Y1R lacking the NHERF2-binding DTSL motif. Thus, NHERF2 selectively restricts downstream coupling of mGluR5 and P2Y1Rs in neurons to $\mathrm{G}_{\mathrm{q}}$-mediated responses such as M-current inhibition. Differential distribution of NHERF2 in neurons may therefore determine coupling of mGluR5 receptors and P2Y1 receptors to calcium channels.
\end{abstract}

\section{Introduction}

The different subtypes of metabotropic receptor for common neurotransmitters usually show a relatively selective interaction with one or other of the main classes of resident G-proteins in neurons. This exerts some constraint on the particular species of ion channel that are affected when the receptors are activated, and hence on the overall response of the neuron to a transmitter. For example, the much-studied neurons of the rat superior cervical sympathetic ganglion possess four subtypes (M1 through M4) (Brown et al., 1995) of the muscarinic acetylcholine receptor (mAChR), but each shows a restricted spectrum of ion channel effects when activated. Thus, the M1-mAChR couples preferentially to $\mathrm{G}_{\mathrm{q}}$ to induce hydrolysis of membrane phosphatidylinositol-4,5bisphosphate $\left(\mathrm{PIP}_{2}\right)$ and so reduce membrane $\mathrm{PIP}_{2}$ levels. This causes the closure of ion channels that require high levels of $\mathrm{PIP}_{2}$ for their activation, such as M-type (Kv7.2/7.3) potassium channels and N-type $\left(\mathrm{Ca}_{\mathrm{v}} 2.2\right)$ calcium channels (for review, see Gamper and

Received May 20, 2010; revised June 25, 2010; accepted June 29, 2010.

This work was supported by Grants 081706 and 089370 from the Wellcome Trust. We thank Dr. R. Hall (Emory University, Atlanta, GA) and Dr. S. R. Ikeda (National Institutes of Health/National Institute on Alcohol Abuse and Alcoholism/Division of Intramural Clinical and Biological Research, Bethesda, Maryland) for gifts of NHERF2-EGFP-C2 and mGluR5a CDNA plasmids, respectively, and J. Reilly (University College London) for help with tissue culture and with plasmid preparation and amplification.

Correspondence should be addressed to Dr. Alexander K. Filippov, Department of Neuroscience, Physiology, and Pharmacology, University College London, London WC1E 6BT, United Kingdom. E-mail: a.filippov@ ucl.ac.uk.

DOI:10.1523/JNEUROSCI.2597-10.2010

Copyright $\odot 2010$ the authors $\quad 0270-6474 / 10 / 3011068-05 \$ 15.00 / 0$
Shapiro, 2007). In contrast, the M4-mAChR selectively couples to $G_{o}$ (Caulfield et al., 1994) and also inhibits the $\mathrm{Ca}_{\mathrm{v}} 2.2$ channel through an action of the $G_{o} \beta \gamma$ subunits (Delmas et al., 1998), but does not affect the M channel. This action is shared by the endogenous $\alpha_{2}$ adrenergic receptor (Herlitze et al., 1996; Ikeda, 1996). Finally, the M2-mAChR does not inhibit the $\mathrm{Ca}_{\mathrm{V}} 2.2$ channel (FernandezFernandez et al., 1999) but instead preferentially couples to $G_{i}$ and activates inwardly rectifying Kir3.1/3.2 channels, which the M4mAChR does not (Fernández-Fernández et al., 2001).

In contrast, we found that the P2Y1 nucleotide receptor (P2Y1R), when expressed in these neurons, coupled with equal facility to G-proteins of both $\mathrm{G}_{\mathrm{q} / 11}$ and $\mathrm{G}_{\mathrm{i} / \mathrm{o}}$ classes. Hence, when activated, it reproduced the effects of stimulating all of the muscarinic receptor types in sympathetic neurons-inhibition of $\mathrm{M}$ and $\mathrm{Ca}_{\mathrm{V}} 2.2$ currents, and sequential activation and inhibition of Kir currents (Brown et al., 2000; Filippov et al., 2000, 2004). This is surprising because in its other responses P2Y1R acts as a $G_{q / 11^{-}}$ selective receptor (Abbracchio et al., 2006).

Responses to metabotropic receptor activation are frequently controlled by ancillary "scaffold" proteins (Kreienkamp, 2002; Bockaert et al., 2010). One such scaffold protein that binds to the P2Y1R is the type- $2 \mathrm{Na}^{+} / \mathrm{H}^{+}$exchange regulatory factor (NHERF2): this augments the $\mathrm{G}_{\mathrm{q}}$-mediated responses to P2Y1R stimulation when coexpressed in cell lines (Fam et al., 2005). We therefore wondered whether NHERF2 might also restrict P2Y1R coupling to $G_{q}$ in neurons. We show that it does so-not by enhancing $\mathrm{G}_{\mathrm{q}}$-mediated $\mathrm{M}$-current inhibition, but by suppressing $\mathrm{G}_{\mathrm{o}}$-mediated $\mathrm{Ca}_{\mathrm{v}} 2.2$ inhibition. We also show that it has a 

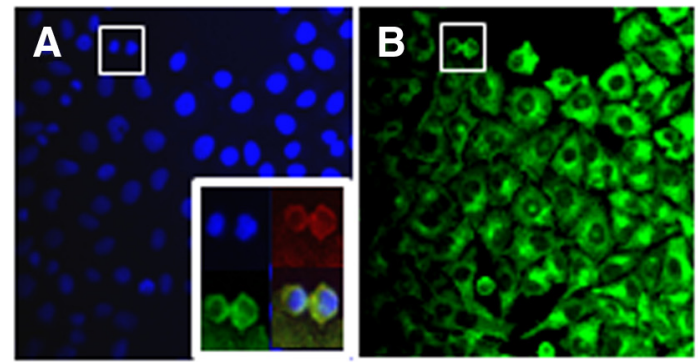

E anti-NHERF2
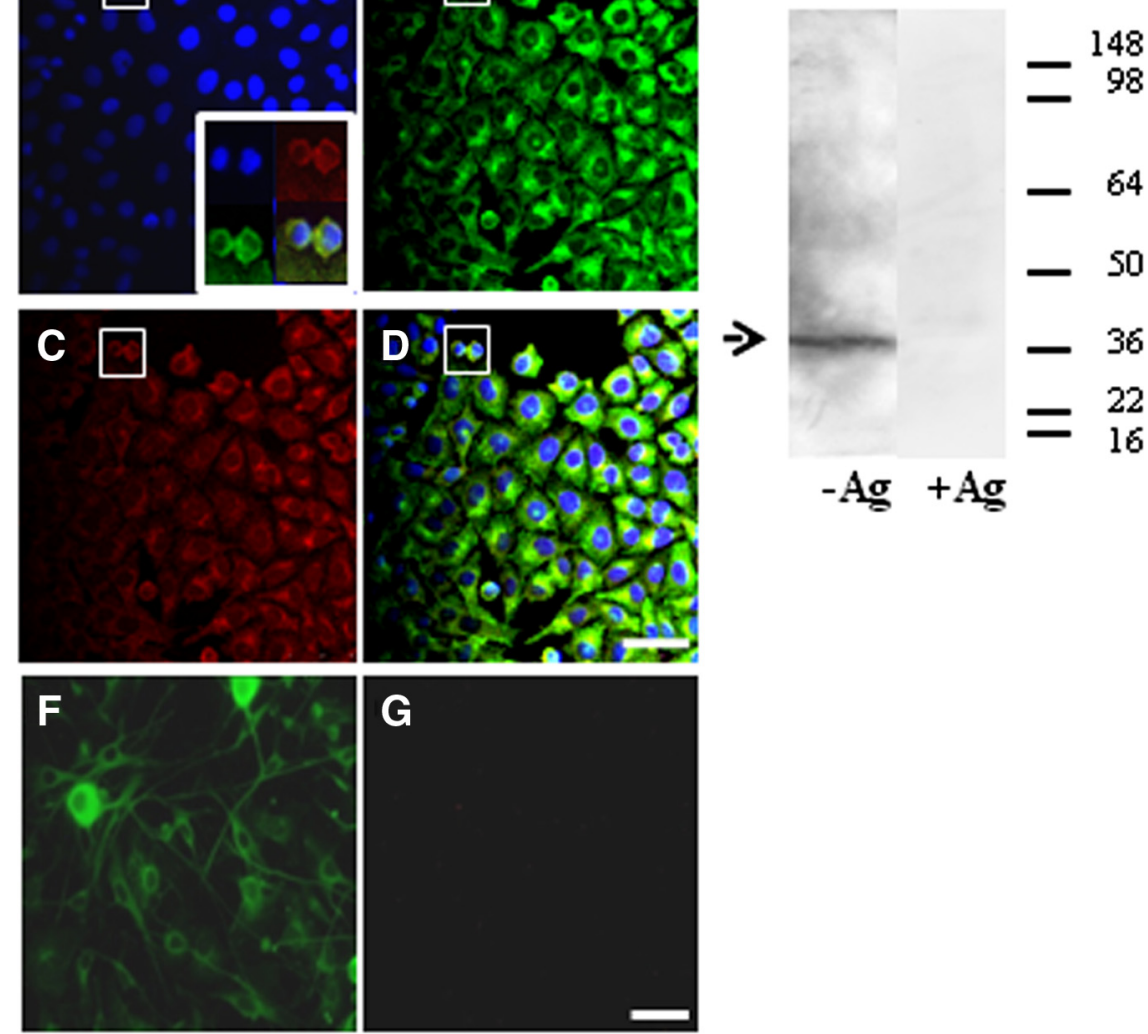

Figure 1. NHERF 2 is endogenous in HEK cells but not in sympathetic neurons. $\boldsymbol{A}-\boldsymbol{D}$, HEK293 cells stably transfected with hP2Y1R cDNA. The same field is stained with $(\boldsymbol{A})$ DAPI (1:1000), to show cell nuclei; $(\boldsymbol{B})$ anti-P2Y1 antibody (1:200), $(\boldsymbol{C})$ anti-NHERF2 antibody (1:100). D, Merged image of the 2 antibody stains, showing strong overlap (yellow). Inset: 2 representative cells in the boxes marked in $\boldsymbol{A}-\boldsymbol{D}$, at higher power, showing the colocalization. Each antibody staining could be fully blocked by its peptide antigen (Ag): for the anti-NHERF2, as shown in Western blots of rat brain membranes (E) showing (unblocked) a single band of the predicted size (37 kDa, see arrow), and in anti-P2Y1R immunostaining [Filippov et al. (2006), their Fig. 2D]. F, G, Rat sympathetic neurons cultured in vitro for 1 week express endogenous P2Y1R immunoreactivity to varying degrees $(\boldsymbol{F})$, but no detectable NHERF2 immunoreactivity (G). Scale bars, $50 \mu \mathrm{m}$.

similar effect on responses of the mGluR5 receptor, another NHERF2-binding partner (Paquet et al., 2006b).

\section{Materials and Methods}

Patch-clamp experiments were performed on neurons dissociated from superior cervical sympathetic ganglia (SCGs) isolated from 17- to 19-d-old rats and cultured for 24-48 h (Filippov et al., 1998). The disrupted patch was used for whole-cell $\mathrm{Ca}^{2+}$ current recordings; an amphotericin-perforated patch was used for M-type potassium current recordings. Currents were recorded with an Axoclamp 2B amplifier and pClamp10 software (Molecular Devices) and analyzed with Origin 5 software (Microcal Software). $\mathrm{Ca}^{2+}$-currents were evoked using $50 \mathrm{~ms}$ pulses from -90 to $0 \mathrm{mV}$ applied every $20 \mathrm{~s}$ and currents measured $7 \mathrm{~ms}$ after beginning the pulse (near to peak current in control). Residual currents in the presence of the $\mathrm{Ca}^{2+}$ channel blocker $\mathrm{CdCl}_{2}(100 \mu \mathrm{M})$, added at the end of experiment, were subtracted. M-current deactivation relaxations were recorded during $1 \mathrm{~s}$ steps from -20 to $-40 \mathrm{mV}$ applied every $20 \mathrm{~s}$, and initial amplitudes were estimated from doubleexponential fitting. For dose-response curves, $\mathrm{M}$-current was measured as holding current at $-20 \mathrm{mV}$ minus the current remaining in the presence of the M-channel blocker XE991, $3 \mu \mathrm{M}$, applied at the end of experiment. Curves were fitted to the data using the Hill equation, $y=y_{\max } \times$ $x^{n H} /\left(x^{n H}+K^{n H}\right)$, where $y=$ observed percentage inhibition, $y_{\max }=$ extrapolated maximal percentage inhibition, $x=$ nucleotide concentration (in nM), $K=\mathrm{IC}_{50}$ (in nM), and $n_{H}=$ Hill coefficient. Data are presented as means \pm SEM. Student's $t$ test was applied to determine statistical significance. The difference was considered significant if $p \leq 0.05$.
Patch pipettes were filled with the following (in mM): $90 \mathrm{KOOCCH}_{3}, 20 \mathrm{KCl}, 3 \mathrm{MgCl}_{2}, 40$ HEPES, 0.1 BAPTA, and $0.125 \mathrm{mg} / \mathrm{ml}$ amphotericin $\mathrm{B}$ (adjusted to $\mathrm{pH} 7.4$ by $\mathrm{KOH}$ ) for $\mathrm{M}$ current, and with $\mathrm{CsCl} 110, \mathrm{MgCl}_{2} 3$, HEPES 40, EGTA 3, $\mathrm{Na}_{2}$ ATP 2, and $\mathrm{Na}_{2}$ GTP 0.5 (pH adjusted to 7.4 with $\mathrm{CsOH}$ ) for $\mathrm{Ca}^{2+}$ current. For M-current recordings, cells were perfused at $15-20 \mathrm{ml} / \mathrm{min}$ with a solution containing the following (in mM): $\mathrm{NaCl} 120, \mathrm{KCl} 3, \mathrm{MgCl}_{2} 1.5$, $\mathrm{CaCl}_{2}$ 2.5, HEPES 10, glucose 11.1, tetrodotoxin 0.0005 , and adjusted to $\mathrm{pH} 7.4$ with $\mathrm{NaOH}$. For $\mathrm{Ca}^{2+}$ current recordings, tetraethylammonium $\mathrm{Cl}$ was substituted for $\mathrm{NaCl}$ and $\mathrm{Ca}^{2+}$ replaced by $5 \mathrm{~mm} \mathrm{Ba}^{2+}$.

Proteins were expressed in neurons by intranuclear cDNA injection performed $5 \mathrm{~h}$ after plating the cells, and recordings were made after overnight incubation (Filippov et al., 2000). EGFP-C1 cDNA was coinjected as a marker of expression when necessary. NHERF2-EGFP-C2 cDNA plasmid was a gift from Dr. R. Hall (Emory University, Atlanta, GA), and mGluR5a cDNA was a gift from Dr. S. R. Ikeda (National Institutes of Health/National Institute on Alcohol Abuse and Alcoholism/Division of Intramural Clinical and Biological Research, Bethesda, Maryland). Mutant (-DTSL) P2Y1R cDNA was previously prepared in our Cambridge laboratory (Choi et al., 2008). cDNAs were injected at the following concentrations (in $\mathrm{ng} / \mu \mathrm{l}$ ): NHERF2 100; mGluR5a 10, P2Y1R as indicated in the text, mutant P2Y1R 1, and EGFP-C1 25.

Immunocytochemistry. Western blotting of rat brain membranes, stained with a NHERF2specific antibody (ab40825, Abcam) was as described by Choi et al. (2008). Immunostaining of cell cultures was as described for hippocampal neurons (Filippov et al., 2006), but using also (with identical results) a custom-made antibody to an extracellular epitope of rat P2Y1R (J. Simon and E. Barnard, unpublished observations). All images were captured in identical conditions by a Leica confocal microscope (SP 5) with excitation (Ex) $405 \mathrm{~nm} / \mathrm{emission}$ (Em) 420 - 470 (blue); Ex 488 nm/Em 500-535 nm (green) and Ex 543 nm/Em 560-615 nm (red).

Chemicals. MRS2365, (S)-3,5-dihydroxyphenylglycine (DHPG) and oxotremorine $\mathrm{M}(\mathrm{OxoM})$ were from Tocris Bioscience; 2MeSADP and norepinephrine from Sigma.

\section{Results}

The scaffold protein NHERF2 is not present in sympathetic neurons

We tested for the presence of NHERF2 in sympathetic neurons using a NHERF2-specific antibody. This antibody gave a single band of predicted NHERF2 size $(37 \mathrm{kDa})$ in brain Western blots (Fig. $1 E$ ) and did not stain the closely related PDZ scaffold protein, NHERF1 (data not shown). HEK293 cells showed clear native NHERF2 immunoreactivity, colocalizing with expressed P2Y1R immunoreactivity (Fig. 1 $A-D$ ). In contrast, no NHERF2 immunoreactivity was detectable in rat SCG neurons (Fig. $1 F, G$ ).

\section{Dual coupling of $\mathrm{P} 2 \mathrm{Y} 1$ receptors to $\mathrm{Ca}^{2+}$ - and $\mathrm{M}$-type $\mathrm{K}^{+}$} channels in SCG neurons is not due to receptor overexpression To check whether dual coupling of expressed P2Y1Rs in sympathetic neurons resulted from receptor overexpression, we varied the P2Y1 cDNA concentration used for intranuclear injections. 
We found that parallel P2Y1R-mediated inhibitions of both $\mathrm{Ca}^{2+}$ - and M-currents were maintained over a >1000-fold cDNA dilution (Fig. 2A). Moreover, activation of the low level of endogenous P2Y1Rs (Fig. $1 F$ ) in the absence of P2Y1RcDNA injection still produced a small inhibition of both $\mathrm{Ca}^{2+}$ - and M-currents. Thus, dual ion channel coupling of P2Y1Rs in sympathetic neurons did not depend on receptor overexpression.

\section{NHERF2 prevents coupling of P2Y1} receptors to $\mathrm{Ca}^{2+}$ channels but not to M channels

Coexpression of NHERF2 scaffold protein with $\mathrm{P} 2 \mathrm{Y} 1$ receptors prevented P2Y1R-mediated inhibition of $\mathrm{Ca}^{2+}$ current but did not change the inhibition of M current (Figs. 2B, 3). Thus, doseresponse curves showed complete suppression by NHERF 2 of the $\mathrm{Ca}^{2+}$-current inhibition by the specific P2Y1R agonist MRS2365 (Fig. 3). In contrast, there was no significant difference between the $\mathrm{IC}_{50}$ values for $\mathrm{M}$-current inhibition, or the maximal current inhibition, with or without NHERF2 expression. Mean values of Hill-plot constants (see Materials and Methods) were as follows: for $\mathrm{Ca}^{2+}$ current inhibition without NHERF2 ( $n=$ 3): $y_{\max }=34.5 \pm 1.3 \% ; K=1.5 \pm 0.2 \mathrm{nM}$; $n_{H}=1.2 \pm 0.2$; with NHERF2 $(n=4)$ : no inhibition; for M-current inhibition without NHERF2 $(n=3): y_{\max }=33.6 \pm$ $0.8 \% ; K=0.8 \pm 0.1 \mathrm{nM} ; n_{H}=1.0 \pm 0.1$; and with NHERF2 $(n=3): y_{\max }=32.0 \pm$ $0.8 \% ; K=0.5 \pm 0.1 \mathrm{nM} ; n_{H}=0.9 \pm 0.1$.

The DTSL motif at the $\mathrm{C}$ terminus of $\mathrm{P} 2 \mathrm{Y} 1 \mathrm{R}$ is critical for P2Y1R binding to NHERF2 (Fam et al., 2005). Hence, we checked whether NHERF2 could modulate $\mathrm{Ca}^{2+}$-channel coupling of a mutated $\mathrm{P} 2 \mathrm{Y} 1 \mathrm{R}$ receptor in which the DTSL binding motif was deleted. $\mathrm{Ca}^{2+}$-current inhibition by this mutant receptor was unaffected by NHERF2 (Fig. $2 B$ ).

NHERF2 had no effect on adrenergic receptor suppression of $\mathrm{Ca}^{2+}$ current by norepinephrine (Fig. $2 B$ ). It also had no effect on muscarinic receptor suppression of $M$ current by oxotremorine-M (Fig. $2 B$ ). Hence, its site of action was not at the $\mathrm{Ca}^{2+}$ channel, nor its modulation by $G_{o}$, but was specific to the P2Y1R.

\section{NHERF2 prevents coupling of mGluR5 receptors to $\mathrm{Ca}^{2+}$ channels but not to $M$ channels}

As with the nucleotide P2Y1Rs, expressed glutamate mGluR5 receptors also show promiscuous ion channel coupling in sympathetic neurons: their stimulation inhibits M-type [Kv7, K(M)] potassium currents and $\mathrm{N}$-type $\left(\mathrm{Ca}_{\mathrm{V}} 2.2\right)$ calcium currents, and these effects are mediated by $\mathrm{G}_{\mathrm{q}}$ and $\mathrm{G}_{\mathrm{i} / \mathrm{o}}$ G-proteins, respectively (Kammermeier and Ikeda, 1999). Also like P2Y1 receptors, mGluR5 receptors bind to NHERF2, and this augments $\mathrm{G}_{\mathrm{q}^{-}}$
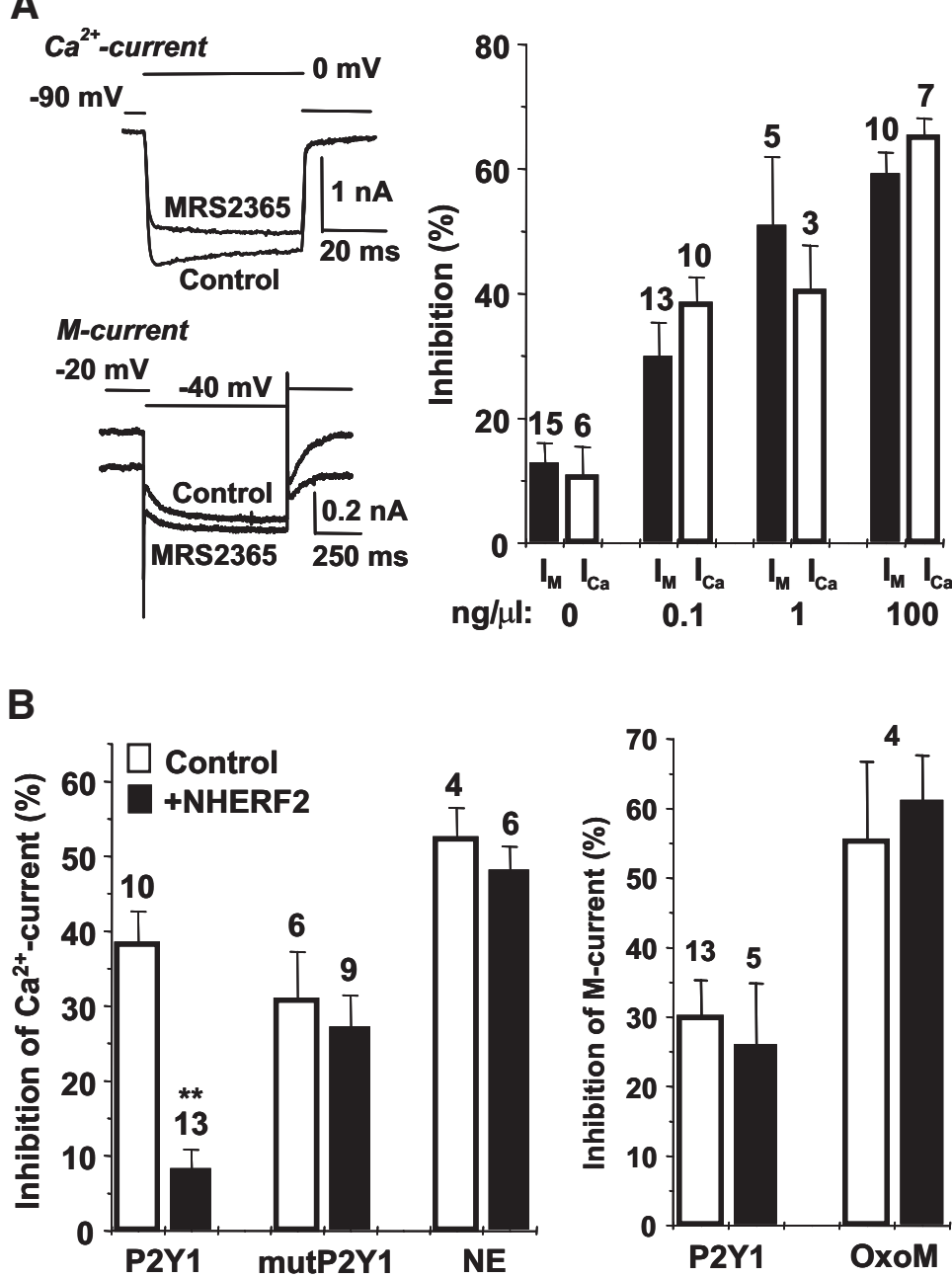

Figure2. A, Activation of endogenous and expressed $\mathrm{P} 2 \mathrm{Y} 1$ receptors produces parallel inhibition of $\mathrm{Ca}^{2+}$ current and $\mathrm{M}$ current in rat sympathetic neurons. Records (left panel) show representative traces of $\mathrm{Ca}^{2+}$ current $\left(\mathrm{I}_{\mathrm{Ca}}\right)$ and $\mathrm{M}$ current $\left(\mathrm{I}_{\mathrm{M}}\right)$ inhibition respectively, by the P2Y1-specific agonist MRS2365 (10 nM). The voltage protocol is shown above the traces. P2Y1 cDNA $0.1 \mathrm{ng} / \mu \mathrm{l}$. eurons injected with different concentrations of P2Y1R cDNA. No difference was seen using these two agonists; MRS2365 was nt to $M$ channels. Bar chart (left) shows inhibition of $\mathrm{Ca}^{2+}$-channel current by the P2Y1R-specific agonist, MRS2365 (10 nM) in NHERF2 CDNA. NHERF2 prevents inhibition of $\mathrm{Ca}^{2+}$-channel current via the wild-type P2Y1 receptor but not via the mutant receptor that does not bind NHERF2. In contrast NHERF2 does not prevent adrenergic inhibition of $\mathrm{Ca}^{2+}$-channel current by norepinephrine (NE, $10 \mu \mathrm{M}$ ) or P2Y1R-mediated inhibition of M current (right panel bar chart) by $1 \mu \mathrm{m} 2 \mathrm{MeSADP}$, or muscarinic suppression of $\mathrm{M}$ current by $0 \times \mathrm{xoM}, 10 \mu \mathrm{m}$. Numbers over bars $=$ number of cells. ${ }^{* *} p<0.001$ (difference from control).

mediated $\mathrm{Ca}^{2+}$ signaling in cell lines (Paquet et al., 2006b). Hence, we tested whether NHERF2 can modulate mGluR5 coupling to $\mathrm{Ca}^{2+}$ channels and to M-type $\mathrm{K}^{+}$channels. We found that expression of NHERF2 selectively suppressed mGluR5mediated $\mathrm{Ca}^{2+}$-current inhibition without effect on M-current inhibition (Fig. 4), just like its effect on P2Y1R signaling.

\section{Discussion}

The main conclusion from these experiments is that the scaffold protein NHERF2 is capable of selectively directing the coupling of the NHERF2-binding receptors P2Y1R and mGluR5 to $\mathrm{G}_{\mathrm{q}}$ coupled ion channels in effects such as inhibition of $\mathrm{M}$ current, at the expense of $\mathrm{G}_{\mathrm{o}}$-dependent effects such as inhibition of $\mathrm{Ca}_{\mathrm{V}} 2.2$ channels. This is not due to an enhancement of the $\mathrm{G}_{\mathrm{q}} / \mathrm{M}$ - 

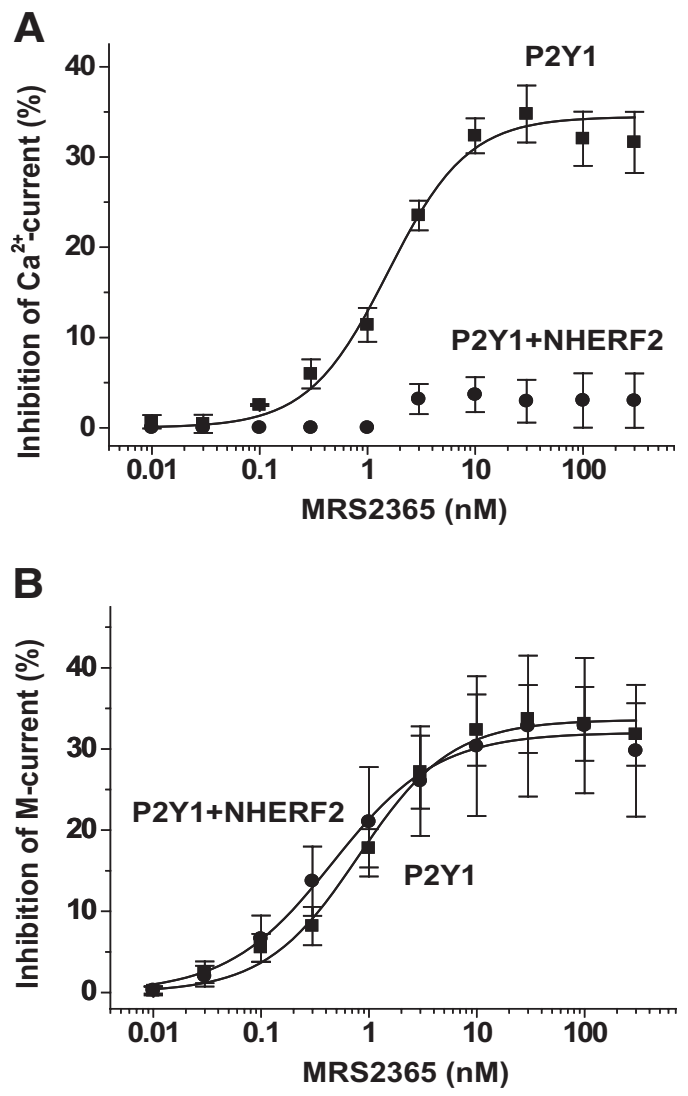

Figure 3. NHERF2 completely blocks P2Y1R-mediated inhibition of $\mathrm{Ca}^{2+}$ current without change of M-current inhibition. $\boldsymbol{A}, \boldsymbol{B}$, Dose-response curves for $\mathrm{Ca}^{2+}$-current inhibition $(\boldsymbol{A})$ and M-current inhibition ( $\boldsymbol{B}$ ) by MRS2365. Curves were fitted to the means (shown, with SEM bars) using the Hill equation (see Materials and Methods). SCG neurons were injected one night before with $1 \mathrm{ng} / \mu \mathrm{I}$ P2Y1 CDNA without (squares) or with (circles) NHERF2 CDNA.

channel effect (as might have been predicted from previous experiments on $\mathrm{G}_{\mathrm{q}}$-mediated responses in non-neural cells) (Fam et al., 2005; Paquet et al., 2006b), since M-channel inhibition was quantitatively unchanged by NHERF2. The reasons for this are probably that $\mathrm{M}$-channel inhibition by muscarinic agonists in these neurons results from the fall in membrane $\mathrm{PIP}_{2}$ following $\mathrm{PIP}_{2}$ hydrolysis, not from the action of products of $\mathrm{PIP}_{2}$ hydrolysis (Winks et al., 2005), and that the limiting factor is the supply of phospholipase $\mathrm{C}$ rather than the extent of $\mathrm{G}_{\mathrm{q}}$ activation (Jensen et al., 2009). Instead, it could be attributed to a virtually complete suppression of $\mathrm{G}_{\mathrm{o}}$-mediated $\mathrm{Ca}^{2+}$-current inhibition.

This suppression appears to be directed at the first stage on the signaling pathway-the interaction of the receptor with the Gprotein - since the equivalent response to norepinephrine was unchanged. In the case of the P2Y1R, it required binding of a PDZ domain of NHERF2 to the previously reported DTSL motif on the receptor $C$ terminus (Fam et al., 2005), since the $\mathrm{Ca}^{2+}$ channel coupling of a mutant P2Y1R devoid of this sequence was unaffected by NHERF2. It might well involve the equivalent domain (SSSL) in the mGluR5 receptor, although we have not yet tested this. Two other sites within the total 46-residue tail have been found to be involved in P2Y1R $\mathrm{G}_{\mathrm{q}}$ coupling (Fam et al., 2003; Ding et al., 2005), but both effects are independent of the presence of the terminal DTSL. Directional control of G-protein coupling by cognate receptors may be a general property of NHERF2 since it has previously been reported to switch the coupling of the parathyroid hormone receptor PTHR from $\mathrm{G}_{\mathrm{s}}$ to $\mathrm{G}_{\mathrm{i} / \mathrm{o}}$ (Mahon et al., 2002).
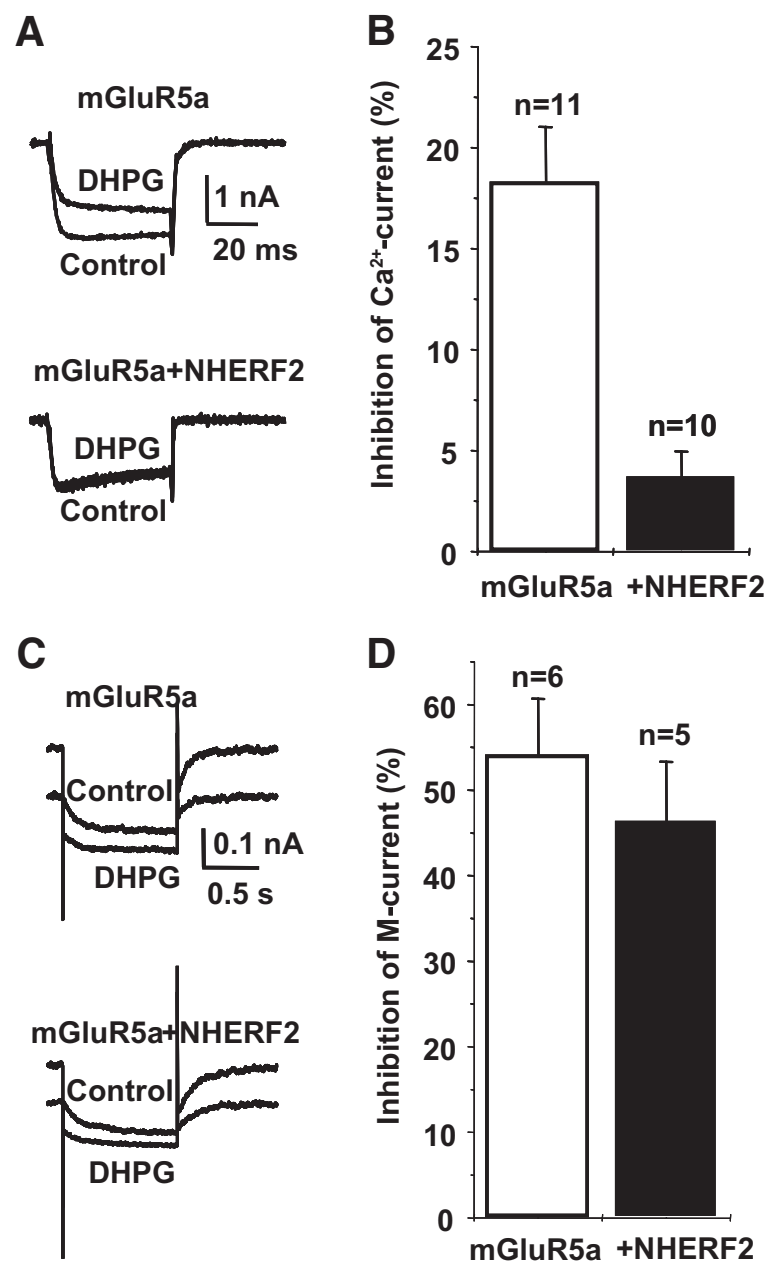

Figure 4. NHERF2 selectively prevents mGluR5a-mediated inhibition of $\mathrm{Ca}^{2+}$ current but not that of $\mathrm{M}$ current. $\boldsymbol{A}, \boldsymbol{C}$, Records show representative traces of $\mathrm{Ca}^{2+}$-current $(\boldsymbol{A})$ and M-current $(\boldsymbol{C})$ inhibition, respectively, by the mGluR5 agonist DHPG $(10 \mu \mathrm{M})$ in SCG neurons injected with mGluR5a CDNA without or with NHERF2 CDNA. The voltage protocol is as for Figure 2. $\boldsymbol{B}, \boldsymbol{D}$, Bar charts show mean inhibition of $\mathrm{Ca}^{2+}$ current $(\boldsymbol{B})$ and $M$ current $(\boldsymbol{D})$ by DHPG in SCG neurons without or with NHERF2. $n=$ number of cells.

Metabotropic glutamate receptors have previously been noted to link to other scaffold proteins. Thus, group 1 mGluRs receptors (including mGluR5) can also bind to Homer to form macromolecular signaling complexes (for review, see Enz, 2007), Homer proteins have been reported to regulate coupling of group 1 mGluRs to neuronal $\mathrm{Ca}^{2+}$ - and $\mathrm{M}$-type $\mathrm{K}^{+}$channels; however, in this case, expression of the long-form Homer protein reduces inhibition of both channels, rather than selectively directing coupling to one or the other (Kammermeier et al., 2000).

Scaffold proteins are known to play an important role in G-protein-coupled signaling in the brain. For example, uncoupling of the PDZ-interacting protein PICK1 from mGluR7 prevents mGluR7-mediated inhibition of $\mathrm{Ca}^{2+}$ current in cerebellar granule cells and causes absence epilepsy in rodents (Bertaso et al., 2008). NHERF2 is present in the brain (Lee et al., 2007), where it is associated with both glia and neurons (Paquet et al., 2006a); preliminary immunocytochemical information indicates that it is strongly expressed in hippocampal pyramidal neurons (E. A. Barnard and J. Simon, unpublished observations). If it exerted comparable effects in central neurons to those we have observed in sympathetic neurons, it could (for example) serve to suppress $\mathrm{G}_{\mathrm{o}}$-mediated inhibitory effects of P2Y1Rs and mGluR5s on $\mathrm{Ca}^{2+}$ 
channels (and hence on transmitter release) while preserving their postsynaptic $\mathrm{G}_{\mathrm{q}}$-mediated excitatory effects (Mannaioni et al., 2001; Filippov et al., 2006).

\section{References}

Abbracchio MP, Burnstock G, Boeynaems JM, Barnard EA, Boyer JL, Kennedy C, Knight GE, Fumagalli M, Gachet C, Jacobson KA, Weisman GA (2006) International Union of Pharmacology LVIII: update on the P2Y G protein-coupled nucleotide receptors: from molecular mechanisms and pathophysiology to therapy. Pharmacol Rev 58:281-341.

Bertaso F, Zhang C, Scheschonka A, de Bock F, Fontanaud P, Marin P, Huganir RL, Betz H, Bockaert J, Fagni L, Lerner-Natoli M (2008) PICK1 uncoupling from mGluR7a causes absence-like seizures. Nat Neurosci 11:940-948.

Bockaert J, Perroy J, Bécamel C, Marin P, Fagni L (2010) GPCR interacting proteins (GIPs) in the nervous system: roles in physiology and pathologies. Annu Rev Pharmacol Toxicol 50:89-109.

Brown DA, Buckley NJ, Caulfield MP, Duffy SM, Jones S, Lamas JA, Marsh SJ, Robbins J and Selyanko AA. (1995) Coupling of muscarinic acetylcholine receptors to neural ion channels: closure of $\mathrm{K}^{+}$channels. In: Molecular mechanisms of muscarinic acetylcholine receptor function (J. Wess, ed), pp 164-182. Austin, TX: R.G. Landes.

Brown DA, Filippov AK, Barnard EA (2000) Inhibition of potassium and calcium currents in neurones by molecularly-defined P2Y receptors. J Auton Nerv Syst 81:31-36.

Caulfield MP, Jones S, Vallis Y, Buckley NJ, Kim GD, Milligan G, Brown DA (1994) Muscarinic M-current inhibition via G alpha q/11 and alphaadrenoceptor inhibition of $\mathrm{Ca} 2+$ current via $\mathrm{G}$ alpha o in rat sympathetic neurones. J Physiol 477:415-422.

Choi RC, Simon J, Tsim KW, Barnard EA (2008) Constitutive and agonistinduced dimerizations of the P2Y1 receptor: relationship to internalization and scaffolding. J Biol Chem 283:11050-11063.

Delmas P, Abogadie FC, Dayrell M, Haley JE, Milligan G, Caulfield MP, Brown DA, Buckley NJ (1998) G-proteins and G-protein subunits mediating cholinergic inhibition of $\mathrm{N}$-type calcium currents in sympathetic neurons. Eur J Neurosci 10:1654-1666.

Ding Z, Tuluc F, Bandivadekar KR, Zhang L, Jin J, Kunapuli SP (2005) Arg333 and Arg334 in the COOH terminus of the human P2Y(1) receptor are crucial for G(q) coupling. Am J Physiol Cell Physiol 288:C559-C567.

Enz R (2007) The trick of the tail: protein-protein interactions of metabotropic glutamate receptors. Bioessays 29:60-73.

Fam SR, Gallagher CJ, Kalia LV, Salter MW (2003) Differential frequency dependence of $\mathrm{P} 2 \mathrm{Y}(1)$ - and $\mathrm{P} 2 \mathrm{Y}(2)$ mediated $\mathrm{Ca}^{2+}$ signaling in astrocytes. J Neurosci 23:4437-4444.

Fam SR, Paquet M, Castleberry AM, Oller H, Lee CJ, Traynelis SF, Smith Y, Yun CC, Hall RA (2005) P2Y1 receptor signaling is controlled by interaction with the PDZ scaffold NHERF-2. Proc Natl Acad Sci U S A 102:8042-8047.

Fernandez-Fernandez JM, Wanaverbecq N, Halley P, Caulfield MP, Brown DA (1999) Selective activation of heterologously expressed G proteingated $\mathrm{K}+$ channels by $\mathrm{M} 2$ muscarinic receptors in rat sympathetic neurones. J Physiol 515:631-637.

Fernández-Fernández JM, Abogadie FC, Milligan G, Delmas P, Brown DA (2001) Multiple pertussis toxin-sensitive G-proteins can couple receptors to GIRK channels in rat sympathetic neurons when expressed heterologously, but only native G(i)-proteins do so in situ. Eur J Neurosci 14:283-292.

Filippov AK, Webb TE, Barnard EA, Brown DA (1998) P2Y2 nucleotide receptors expressed heterologously in sympathetic neurons inhibit both N-type $\mathrm{Ca}^{2+}$ and M-type K+ currents. J Neurosci 18:5170-5179.

Filippov AK, Brown DA, Barnard EA (2000) The P2Y(1) receptor closes the $\mathrm{N}$-type $\mathrm{Ca}(2+)$ channel in neurones, with both adenosine triphosphates and diphosphates as potent agonists. Br J Pharmacol 129:1063-1066.

Filippov AK, Fernández-Fernández JM, Marsh SJ, Simon J, Barnard EA, Brown DA (2004) Activation and inhibition of neuronal G proteingated inwardly rectifying $\mathrm{K}(+)$ channels by $\mathrm{P} 2 \mathrm{Y}$ nucleotide receptors. Mol Pharmacol 66:468-477.

Filippov AK, Choi RC, Simon J, Barnard EA, Brown DA (2006) Activation of $\mathrm{P} 2 \mathrm{Y} 1$ nucleotide receptors induces inhibition of the M-type $\mathrm{K}^{+}$current in rat hippocampal pyramidal neurons. J Neurosci 26:9340-9348.

Gamper N, Shapiro MS (2007) Regulation of ion transport proteins by membrane phosphoinositides. Nat Rev Neurosci 8:921-934.

Herlitze S, Garcia DE, Mackie K, Hille B, Scheuer T, Catterall WA (1996) Modulation of $\mathrm{Ca} 2+$ channels by G-protein beta gamma subunits. Nature 380:258-262.

Ikeda SR (1996) Voltage-dependent modulation of N-type calcium channels by G-protein beta gamma subunits. Nature 380:255-258.

Jensen JB, Lyssand JS, Hague C, Hille B (2009) Fluorescence changes reveal kinetic steps of muscarinic receptor-mediated modulation of phosphoinositides and Kv7.2/7.3 K+ channels. J Gen Physiol 133:347-359.

Kammermeier PJ, Ikeda SR (1999) Expression of RGS2 alters the coupling of metabotropic glutamate receptor la to M-type $\mathrm{K}+$ and N-type Ca2 + channels. Neuron 22:819-829.

Kammermeier PJ, Xiao B, Tu JC, Worley PF, Ikeda SR (2000) Homer proteins regulate coupling of group I metabotropic glutamate receptors to N-type calcium and M-type potassium channels. J Neurosci 20:72387245 .

Kreienkamp HJ (2002) Organisation of G-protein-coupled receptor signalling complexes by scaffolding proteins. Curr Opin Pharmacol 2:581-586.

Lechner SG, Dorostkar MM, Mayer M, Edelbauer H, Pankevych H, Boehm S (2004) Autoinhibition of transmitter release from PC12 cells and sympathetic neurons through a $\mathrm{P} 2 \mathrm{Y}$ receptor-mediated inhibition of voltagegated Ca2 + channels. Eur J Neurosci 20:2917-2928.

Lee A, Rayfield A, Hryciw DH, Ma TA, Wang D, Pow D, Broer S, Yun C, Poronnik P (2007) $\mathrm{Na}+-\mathrm{H}+$ exchanger regulatory factor 1 is a PDZ scaffold for the astroglial glutamate transporter GLAST. Glia 55:119-129.

Mahon MJ, Donowitz M, Yun CC, Segre GV (2002) $\mathrm{Na}(+) / \mathrm{H}(+)$ exchanger regulatory factor 2 directs parathyroid hormone 1 receptor signalling. Nature 417:858-861.

Mannaioni G, Marino MJ, Valenti O, Traynelis SF, Conn PJ (2001) Metabotropic glutamate receptors 1 and 5 differentially regulate CA1 pyramidal cell function. J Neurosci 21:5925-5934.

Paquet M, Kuwajima M, Yun CC, Smith Y, Hall RA (2006a) Astrocytic and neuronal localization of the scaffold protein $\mathrm{Na}+/ \mathrm{H}+$ exchanger regulatory factor 2 (NHERF-2) in mouse brain. J Comp Neurol 494:752-762.

Paquet M, Asay MJ, Fam SR, Inuzuka H, Castleberry AM, Oller H, Smith Y, Yun CC, Traynelis SF, Hall RA (2006b) The PDZ scaffold NHERF-2 interacts with mGluR5 and regulates receptor activity. J Biol Chem 281:29949-29961.

Simon J, Filippov AK, Göransson S, Wong YH, Frelin C, Michel AD, Brown DA, Barnard EA (2002) Characterization and channel coupling of the P2Y(12) nucleotide receptor of brain capillary endothelial cells. J Biol Chem 277:31390-31400.

Winks JS, Hughes S, Filippov AK, Tatulian L, Abogadie FC, Brown DA, Marsh SJ (2005) Relationship between membrane phosphatidylinositol-4,5bisphosphate and receptor-mediated inhibition of native neuronal $\mathrm{M}$ channels. J Neurosci 25:3400-3413. 